\title{
Development of a Dispersal Model for Balsam Woolly Adelgid, Adelges piceae Ratzeburg (Hemiptera: Adelgidae), to Facilitate Landscape-Level Management Planning
}

\author{
L. W. Lass, S. P. Cook, B. Shafii, and T. S. Prather \\ Department of Plant, Soil and Entomological Sciences, University of Idaho, Moscow, ID 83844-2339, USA \\ Correspondence should be addressed to L. W. Lass; llass@uidaho.edu
}

Received 30 August 2013; Revised 23 October 2013; Accepted 7 November 2013; Published 5 February 2014

Academic Editor: Scott D. Roberts

Copyright @ 2014 L. W. Lass et al. This is an open access article distributed under the Creative Commons Attribution License, which permits unrestricted use, distribution, and reproduction in any medium, provided the original work is properly cited.

\begin{abstract}
The balsam woolly adelgid (Adelges piceae Ratzeburg) attacks subalpine fir (Abies lasiocarpa (Hook.) Nutt.) in eastern Washington, Oregon, and northern Idaho. Historical balsam woolly adelgid distributions present an opportunity to understand climatic factors that influence the species' distribution at a landscape scale. The distribution data allows for creation of predictive models that detail the likelihood of occurrence and associated geographic data allow modeling of species dispersal. Predictive variables linked to the distribution of the hosts and to abiotic environmental conditions were utilized to create a spatial probability model of occurrence. Balsam woolly adelgid predominantly disperses by wind, and hence, both wind speed and wind direction were used to create a dispersal probability model. Results from wind dispersal modeling suggested that two-thirds of the new infestations were due to July and August wind direction and speed. Average July winds ranged from 0.5 to $3.27 \mathrm{~m} / \mathrm{s}$, flowing south westerly, and August winds ranged from 0.43 to $1.55 \mathrm{~m} / \mathrm{s}$, flowing north easterly. Land managers can use the results of the predictive model to better understand where current infestations are likely to expand. Prediction of where the balsam woolly adelgid might move allows managers to adjust actions to respond to future insect movement and establishment.
\end{abstract}

\section{Introduction}

Invasive species represent a serious threat to the health and productivity of natural systems throughout North America. Balsam woolly adelgid, Adelges piceae (Ratzeburg) (Hemiptera: Adelgidae), an insect native to the fir forests of central Europe, was introduced to the United States around 1900 and is considered a pest of native North American true firs [1]. The life cycle of balsam woolly adelgid consists of egg, three larval instars, and adult female stages [2]. The only life stage capable of movement is the first instar larva (termed the crawler) that, upon locating a suitable feeding site, inserts its stylet into the bark and transforms (without molting) into a neosistens, after which the insect is permanently attached to the host tree. The insect secretes a dense waxy covering, once attached, that ultimately covers the entire insect. The crawler does not have wings and dispersal between trees is a passive process with individuals carried primarily by wind. The adult female produces up to 250 eggs that are oviposited within the woolly mass which acts to protect all of the life stages except the crawler [2]. Depending upon local conditions and elevation, balsam woolly adelgid populations can have from 2 to 4 generations annually. Two generations per year are common in the mountainous west region of the United States [3].

All native, North American true firs (Abies) show some degree of susceptibility to the balsam woolly adelgid [4]. While grand fir, A. grandis (Douglas $\times D$. Don) Lindley, is present throughout much of the infested area in Idaho, the adelgid is established on subalpine fir, A. lasiocarpa (Hook.) Nutt., where it is responsible for significant levels of mortality [5]. Infestation of firs by the adelgid results in structural changes within the host tissues. Specifically, the xylem tissue of infested trees has higher concentrations of ray tissue $[6,7]$, thickened cell walls, and shorter tracheids [8] that have encrusted pit membranes, more closely resembling the pit membranes associated with heartwoods [9]. There is a corresponding reduction in water flow in infested trees [6] that stresses the tree and reduces photosynthesis and 
respiration [10]. Over time, the crown thins and the foliage fades with a measurable change in green characteristics that can facilitate the identification of infestations [11].

Balsam woolly adelgid is just one of many invasive forest pests in western North America. Management of invasive species across extensive areas is challenging and would benefit from a landscape-level decision support tool. The goal of this project was to predict areas susceptible to invasion by balsam woolly adelgid and to establish the pattern of movement within those areas in order to support efforts to reduce the impact of this invasive species. The hypothesis that we examined was that passive dispersal by balsam woolly adelgid can be explained using readily available wind data.

\section{Materials and Methods}

2.1. Study Area. The encompassing study area, eastern Oregon and Washington, north central Idaho and Western Montana in the United States, was defined as $-119^{\circ}$ to $-112^{\circ}$ longitude and $44^{\circ}$ to $48^{\circ}$ latitude. Data were split into $2^{\circ}$ intervals for the training $\left(-117^{\circ}\right.$ to $-115^{\circ}$ longitude and $44^{\circ}$ to $46^{\circ}$ latitude) and validation $\left(-117^{\circ}\right.$ to $-115^{\circ}$ longitude and $46^{\circ}$ to $48^{\circ}$ latitude) data sets. Wind speed and direction data were acquired from RAWS USA Climate Archive (http://www.raws.dri.edu/index.html) for model creation and from the Weather Underground Inc. website (http://www.wunderground.com/) for validation. RAWS USA compiles data from government owned weather stations while Weather Underground data are compiled from privately owned weather stations.

2.2. Infestation Data. Infestation data of balsam woolly adelgid were obtained from annual aerial detection surveys of insects and pathogens impacting forests within the study area that were conducted by the USDA-Forest Service, Forest Health Protection. These data were collected by human observers and mapped in-flight. Observers used known infestations for visual training cues and a representative sample of new infestations was also verified with ground observations of pest occurrence. Aerial detection surveys mapped balsam woolly adelgid within the study area during 1983. Flight paths did not cover the entire study area on an annual basis, but accumulated flight lines over a consecutive five-year period, providing full coverage. The initial data used for modeling dispersal utilized infestations that accumulated aerial detection surveys from 1983 to 1995 . The validation data comprised the accumulated results from 2005 until 2008 and reflected a 12- to 16-year period of population expansion. Survey data between 1995 and 2005 were not included in this analysis because the project concentrated on long-term spread-over more than 10 years.

All invasive species survey data have some problems with positioning errors and identification accuracy. To offset potential survey bias, large training $\left(79 \mathrm{~km}^{2}\right.$ with infested trees in 1983 to 1995 survey) and validation $\left(350 \mathrm{~km}^{2}\right.$ infested trees in 2005 to 2008 survey) areas were selected. We further selected, at random, balsam woolly adelgid infestations within the training and validation areas to be utilized for subsequent statistical validations. Survey bias from the visual observation was further reduced within the modeling procedure by using a stratified random sampling of $15 \%$ of the infested training pixels [12].

2.3. Estimation of Host Plant Occurrence. Subalpine fir is the dominant host of balsam woolly adelgid in Idaho [5] although grand fir has been reported to be a supportive host [13]. In the Rocky Mountain region, subalpine fir stands grow in full sun sites of cool high-elevation subalpine meadows and in microsites where pockets of cold air collect [14]. Within our study area, the distribution records were recorded on coarse resolution maps that were of limited value for modeling the occurrence of balsam woolly adelgid. Therefore, we used the current occurrence of balsam woolly adelgid infestation locations, knowing they cooccur with subalpine fir. Independent variables pursued to create subalpine fir occurrence model were elevation, slope, aspect, incoming sunlight index [15], stressed vegetation index [16, 17], transformed soil-adjusted vegetation index (TSAV1) [18], spring growing degree days and winter freezing degree day models [19].

Spring growing degree days were derived from PNWPest.org website using daily 30 -year average minimum and maximum temperatures and $4^{\circ} \mathrm{C}$ lower and $35^{\circ} \mathrm{C}$ upper thresholds from February 1 to July 21. Cumulative freezing degree days were derived from PNWPest.org website and using $-5^{\circ} \mathrm{C}$ lower and $10^{\circ} \mathrm{C}$ upper thresholds from January 1 to March 1.

A logistic regression model was used to predict the probability of occurrence of subalpine firs in the area reflecting the potential host distribution of balsam woolly adelgid. The logistic regression model used for estimating the potential occurrence of subalpine fir took the general form:

$$
\begin{aligned}
\operatorname{logit}_{i j} & =\ln \left[\frac{p_{i j}}{\left(1-p_{i j}\right)}\right] \\
& =b_{0}+b_{1} * x_{1}+b_{2} * x_{2}+\cdots+b_{k} * x_{k}+e_{i},
\end{aligned}
$$

where $x_{1}, x_{2}, \ldots, x_{k}$ are explanatory variables, $b_{0}, b_{1}, \ldots, b_{k}$ are the regression coefficients, and $e_{i}$ is the error term under standard regression assumption.

A relative operating characteristic (ROC) analysis was used to determine suitability of the environmental correlate [20] for predicting the occurrence of subalpine fir [21]. Residuals were examined to assess the adequacy of the estimated model. Validation data based on aerial surveys were used to evaluate the amount of overcommitment error rates for the specified model. The best predicted logistic regression model, having the highest ROC, lowest residual, and overcommitment errors, was hardened for the dispersal model, where zero represented areas with less than a $20 \%$ likelihood of occurrence of subalpine fir and one represented areas where likelihood of occurrence of subalpine fir was greater than $20 \%$. The $20 \%$ probability cutoff was based on achieving the lowest commissional error balanced with the lowest omissional error.

2.4. Wind Direction and Speed. Monthly average wind direction and wind speed for July and August were 
downloaded from RAWS USA Climate Archive (http://www .raws.dri.edu/index.html) for all weather stations in the study area $(n=109)$. The number of years used to calculate average wind speed and direction ranged from 4 to 30 depending on available records. Wind direction was converted to radians. Data from stations were removed from the analysis if average wind speed was greater than $10 \mathrm{~m} / \mathrm{s}$ and the adjacent stations did not report these sustained high winds. Data were converted to a vector point file with point identifiers representing wind speed or direction. Surface interpolation using a distance weighted average in a 6-point search radius was used to interpolate values between points and make a raster file for wind direction and speed with a 10 by $10 \mathrm{~m}$ grid [22]. Additional grid sizes of 100 by $100 \mathrm{~m}$ and 500 by $500 \mathrm{~m}$ were tested but dispersal results did not significantly differ from $10 \times 10 \mathrm{~m}$ grids. The interpolated wind direction data were converted back into degrees for the dispersal model.

The interpolated wind speed data were adjusted for topography and vegetation using a multilayer perceptron model [23-25]. In multilayer perceptron modeling a supervised classification of the training data are used to inform a spatial neural network with forward and backward passes between the network nodes (intersection of two vectors) until the network determined the characteristics of all potential interactions between input variables [26-28]. Explanatory variables in the model were TSAV1, land surface feature shape (categorical data describing the surface of the land such as peak, ridge, saddle, flat, ravine, pit, convex hillside, saddle hillside, slope hillside, concave hillside, or inflection hillside), and wind flow (direction flowing from a pixel). The number of training and testing pixels was set to 3500 each, representing $10 \%$ of total available training sites. The learning rate was set to 0.001 and 20,000 iterations. The large number of training pixels, 7 times greater than default and 10 -fold slower learning rate, was used to increase the accuracy when training the model and to reduce calculation errors. The results of the multilayer perceptron model were adjusted to remove estimated negative wind values and speeds greater than $10 \mathrm{~m} / \mathrm{s}$. The adjustment reflected the wind speed range (0 to $10 \mathrm{~m} / \mathrm{s}$ ) recorded by the weather stations in the region. The magnitude force component of the dispersal model was the logarithmic value of adjusted wind speed and ranged from 0 to 1 .

The validation data for wind speed consisted of a network of private and public weather stations. Average wind speed reported from 16 private stations that were not used for multilayer perceptron modeling was contrasted with the predicted magnitude of force. This ensured that the validation data were not using the same weather station and location as the training data and could validate the wind force model results among the government weather stations used for the training. Data from the private weather stations were available for only 2009 and 2010. In July of 2009 and 2010, predicted values were double the values of the validation sites and triple the values during August. This suggests that the wind speed model would overestimate dispersal distance for 2009 and 2010. Results of the validation test were applied to the force variable (wind speed) in the wind model by clustering the predicted speed into 5 speed categories $(20 \%$ incremental increase) instead of using a continuous range
TABLE 1: Predicted new BWA dispersal in validation site.

\begin{tabular}{lccc}
\hline $\begin{array}{l}\text { Distance from } \\
\text { initial } \\
\text { infestation } \\
(\mathrm{km})\end{array}$ & $\begin{array}{c}\text { July wind } \\
\text { model found } \\
\left(\mathrm{km}^{2}\right)\end{array}$ & $\begin{array}{c}\text { August wind } \\
\text { model found } \\
\left(\mathrm{km}^{2}\right)\end{array}$ & $\begin{array}{c}\text { Combined wind } \\
\text { model found } \\
\left(\mathrm{km}^{2}\right)\end{array}$ \\
\hline 0.3 & 18.96 & 44.02 & 52.89 \\
0.6 & 17.61 & 34.23 & 36.23 \\
1.25 & 29.51 & 39.79 & 41.47 \\
2.5 & 29.36 & 48.42 & 46.32 \\
5 & 37.88 & 50.87 & 52.57 \\
\hline $\begin{array}{l}\text { Total found } \\
\text { Total BWA in }\end{array}$ & 133.31 & 217.33 & 229.48 \\
validation & 350.17 & 350.17 & 350.17 \\
$\begin{array}{l}\text { Total area in } \\
\text { validation site }\end{array}$ & 48,018 & 48,018 & 48,018 \\
$\begin{array}{l}\text { Percent } \\
\text { accounted by } \\
\text { dispersal model }\end{array}$ & $38.07 \%$ & $62.06 \%$ & $65.53 \%$ \\
\hline
\end{tabular}

${ }^{1}$ Distance from initial infestation is the calculated minimum dispersal distance found for all initial infestations tested.

from 0 to 1 . This allowed force of the wind model to partly compensate for year to year wind speed variability.

2.5. Dispersal Modeling. Balsam woolly adelgid dispersal by wind was estimated using a spatial network model [15]. Movement along a predefined grid or segment was determined by the rate and direction of travel as defined by the force and direction of the wind through the cells. The resistance to movement along any path can be determined from the summation of all forces (competition, water, light, etc.) linking cells along the path of invasion [29]. The results of the wind speed model were hardened using a logarithmic scale of the wind speed to estimate the magnitude of force (ranging from 0 to 1 ) and clustered in 0.2 intervals to reduce year to year variability. For areas without subalpine firs, the wind speed was set to zero to prevent movement without the host. The dispersal model estimating the expansion of balsam woolly adelgid was iterated until a distance of $5 \mathrm{~km}$ was reached (a distance equal to the mean distance expansion for the insect based upon 15-year survey results within the study area).

\section{Results and Discussion}

3.1. Spatial Distance between Balsam Woolly Adelgid Infestations. Based upon the Euclidean distance between current infestations of balsam woolly adelgid, $57 \%$ of the infestations were within $0.3 \mathrm{~km}$ of other infestations (Table 1). Prior reports of the adelgid in Idaho have primarily focused on range expansion over relatively large areas and less so on the distances between individual infestations (i.e., [5]). Nearly all (97\%) balsam woolly adelgid infestations located by the flight surveys within our study area were located within $5 \mathrm{~km}$ of other infestations. The relative proximity of infestations to each other suggests that short distance dispersal plays an important role in the spread of balsam woolly adelgid. Variogram analysis of short distance dispersal (less 
than $1.5 \mathrm{~km}$ ) demonstrated that spatial continuity was best described in a $120^{\circ}$ direction. If projected dispersal was greater than $3.5 \mathrm{~km}$, two spatial continuity patterns of 0 or $90^{\circ}$ were evident, suggesting that the two wind direction patterns were responsible for the long distance movement. The two patterns reflected a shift in the transport vector(s) in relation to variable speed working to disperse balsam woolly adelgid.

3.2. Occurrence of Subalpine Fir. The logistic regression model estimated the likelihood of occurrence of subalpine fir throughout the study area (Figure 1). Predicted values ranged between 0 and 1 and were hardened into five occurrence classes, representing no likelihood of occurrence, ranging from 0 to 0.1 (white); low occurrence, ranging from 0.1 to 0.2 ; moderate occurrence, ranging from 0.2 to 0.3 ; high occurrence, ranging from 0.3 to 0.5 ; and very high occurrence, ranging from 0.5 to 1 (green). The independent variables used in the occurrence model were elevation, incoming sunlight index (SUN), stressed vegetation index (STVI), spring growing degree day (SGDD), and cumulative freezing degree day (CFDD). The predicted model was given by

$$
\begin{aligned}
\operatorname{logit}_{i j}= & 106.75+(-0.0167 * \mathrm{SUN})+\left(-0.0005 * \mathrm{SUN}^{2}\right) \\
& +(0.0758 * \mathrm{STVI})+\left(-0.0044 * \mathrm{STVI}^{2}\right) \\
& +(-0.0149 * \text { ELEVATION })+(0.0174 * \mathrm{SGDD}) \\
& +(-0.7668 * \text { WCDD }) .
\end{aligned}
$$

The calculated ROC statistic, a summary measure of the model adequacy, was 73\%, and residuals showed consistent patterns with only a few areas of overestimation (Table 2). Further analysis of residuals showed that less than $0.5 \%$ of the study area produced high residuals when modeling the occurrence of subalpine fir. The model overestimated occurrence of subalpine fir by $32 \%$ in areas of low likelihood. Ground truthing of the model was accomplished within 6 sites in Latah and Idaho counties in Idaho and showed no omission at these sites. Results of the logistic regression model further indicated that the area of high and very high likelihood for the occurrence of subalpine fir also had a presence of balsam woolly adelgid infestation. The occurrence of balsam woolly adelgid infestations in areas with high to very high likelihoods of occurrence of subalpine fir suggested that the insect may have spread to all locations in the study area that contained subalpine fir [3].

3.3. Wind Force Magnitude and Direction. Wind direction interpolation results showed different patterns between July and August (Figure 2). In July, the average direction flowed southwesterly, but in August, the winds shifted to a northeast flow. The change in direction between months reflects a general jet stream shift in which warm dry air flows come from the southwest in the Inland Pacific Northwest during the months of August and mid-September. The warm winds of August also resulted in a second wind shift in which cooler night temperatures created nighttime air flow down the

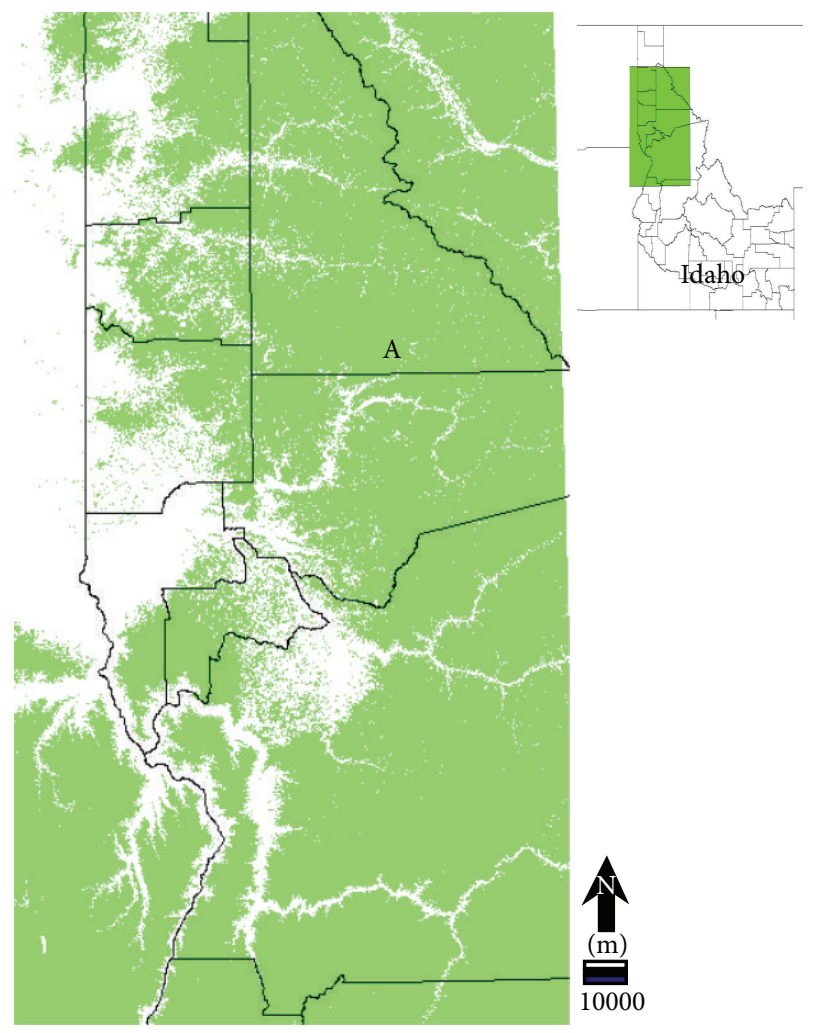

Figure 1: Predicted subalpine fir likelihood of occurrence (green). $\mathrm{A}=$ location of Figures 4 and 5.

TABLE 2: Estimated residuals along with known subalpine fir population within training site for the subalpine fir occurrence model.

\begin{tabular}{lcc}
\hline Estimated residuals & Training site (ha) & Frequency (\%) \\
\hline 0 & $47,761.2$ & 99.5 \\
0.001 to 0.2 & 0.2 & 0.0 \\
0.2 to 0.4 & 0.0 & 0.0 \\
0.4 to 0.6 & 0.0 & 0.0 \\
0.6 to 0.8 & 0.0 & 0.0 \\
0.8 to 1 & 243.5 & 0.5 \\
\hline Total area & 48005.0 & \\
\hline
\end{tabular}

canyons. Regional wind speed estimates for July ranged from 0.56 to $3.27 \mathrm{~m} / \mathrm{s}$ and for August ranged from 0.43 to $1.55 \mathrm{~m} / \mathrm{s}$.

3.4. Wind Dispersal Model. Balsam woolly adelgid can move on infested logs during harvest [30] or by organisms ranging from other insects to birds and small mammals [31]. Similar means of dispersal have been demonstrated for hemlock woolly adelgid, A. tsugae Annand, another invasive adelgid found in North American forests [32]. Although not present in North American populations of hemlock woolly adelgid, the insect has a winged form in its native range. In North America, populations of both balsam woolly adelgid and hemlock woolly adelgid are flightless and dispersal occurs, primarily by wind. Therefore, we focused our efforts on examining wind-based dispersal of the insect within the study area. 


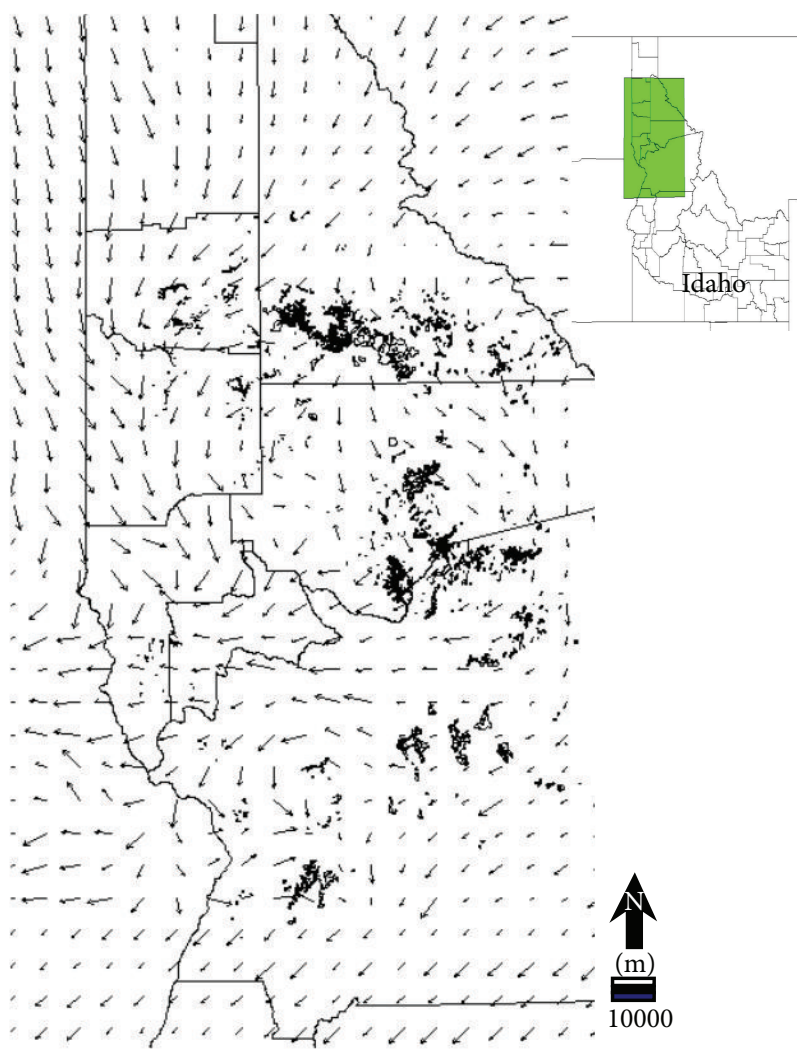

FIGURE 2: July wind plot indicating direction and force in north central Idaho. 1995 balsam woolly adelgid infestations are in black.

Spring development of the adelgid depends upon the elevation at which the insect occurs but typically begins in late April or early May, and by the end of June, most of the population has reached the adult stage [3]. Oviposition occurs and when the crawlers emerge, dispersal can begin. Balsam woolly adelgid has two to four generations per year, but there are no reports of generation numbers or development in high-elevation sites of the majority of the subalpine fir in our study area. Therefore, we constructed our models to evaluate dispersal that would occur slightly later in the summer time, primarily during July and August. We assumed a synchronous dispersal pattern over time and averaged wind direction throughout the month-long periods so as to provide information relevant to the general direction of the dispersal. We further assumed that the adelgids had glide efficiency of $90 \%$ when dispersing in a wind current (i.e., they were carried horizontally less than $0.9 \mathrm{~m} / \mathrm{second}$ when the wind moved $1.0 \mathrm{~m} /$ second) [2]. The glide efficiency is likely greater than $90 \%$ given that the balsam woolly adelgid is nearly weightless [2].

The July wind dispersal model accounted for approximately $38 \%$ of the new balsam woolly adelgid infestations detected in the $48,018 \mathrm{~km}^{2}$ validation area (Table 1). The July dispersal model took 107 iterations for all initial sites in the validation area to reach the distance of $5 \mathrm{~km}$. The July dispersal pattern had a southerly direction (Figure 3 ) but the dispersal pattern failed to align with $62 \%$ of new infestations

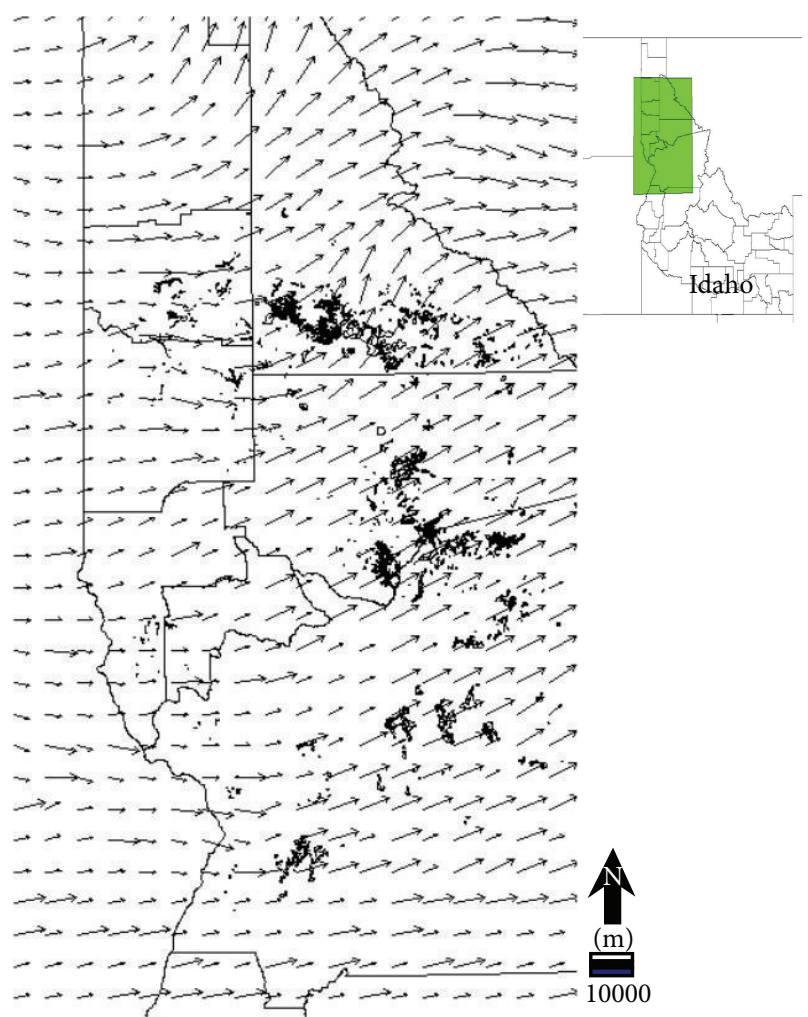

FIgURE 3: August wind plot indicating direction and force in north central Idaho. 1995 balsam woolly adelgid infestations are in black.

occurring 15 years later. In contrast, the August wind dispersal model accounted for approximately $62 \%$ of new balsam woolly adelgid infestations detected in the validation area (Table 1). The August dispersal model required 260 iterations for all initial sites in the validation area to reach the minimum distance of $5 \mathrm{~km}$. The increase in August iterations is a reflection of calmer winds when compared to July wind speeds. The dispersal pattern had a northeasterly wind direction and, compared to the July dispersal model, more closely covered the new infestations reported 15 years later (Figures 4 and 5).

When model overlaps were consolidated, combining the July and August dispersal models accounted for almost 66\% of all new balsam woolly adelgid infestations within the study area (Table 1). This is a slight improvement (4\%) over using the August only model. The wind dispersal models provided insight into when movement of balsam woolly adelgid occurred and suggested the direction of balsam woolly adelgid spread. It is interesting to note that many of the new infestations that were missed by our models are up-slope in elevation from the initial infestations found from 1983 to 1995, which suggests that there may be some upslope convective currents during calmer sunny days or some other factors other than wind are playing a role in dispersal of balsam woolly adelgid across the landscape. Most of the known infestations (approximately 95\%) are within $100 \mathrm{~m}$ of a road or recreational trail. Roads and trails may support betweentree dispersal given that balsam woolly adelgid is more likely to disperse between trees in areas with lower canopy 

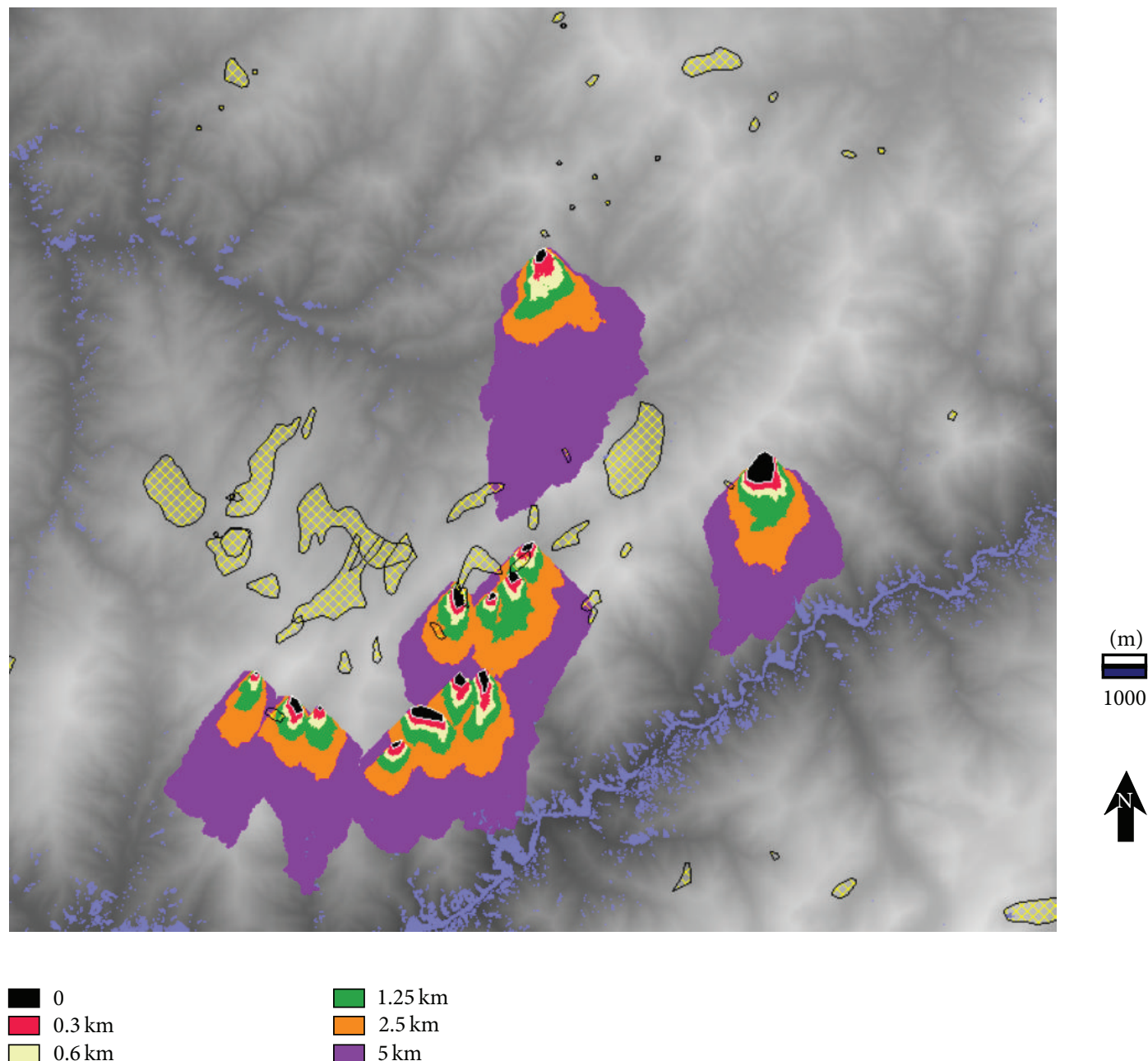

FIGURE 4: July wind dispersal model showing BWA (yellow crosshatched = BWA infestations found 12 to 16 years after initial survey, blue represents area unlikely to have subalpine fir, and background layer is elevation). Location shown in Figure 1.

cover. In addition, balsam woolly adelgid dispersal has been reported to be associated with vertebrate activity, including human movement of the insect $[30,31]$; however, this type of dispersal was beyond the scope of our wind dispersal project.

Within the study area, subalpine fir occurred in disjunctive patches at higher elevations. Prior work on range expansion by balsam woolly adelgid in Idaho concentrated on examining large geographic areas [5]. However, variogrambased spatial distance analysis showed that the majority of infestations were located in relatively close proximity (within $5 \mathrm{~km}$ ) to other infestations (Table 1). When balsam woolly adelgid lands on and successfully attacks subalpine fir in stands, severe damage (including tree mortality of most/all of the subalpine fir present in the stand) can occur. Our study suggests that the timing of dispersal (July versus August) may impact the distance that the insect is carried by the wind, with longer range dispersal occurring later in the season. Also, the best overall estimate of balsam woolly adelgid dispersal was obtained by combining the data for July and August wind parameters. When considering possible movement from infestations found earlier to infestations found later, $92 \%$ were found within $2.5 \mathrm{~km}$ and $97 \%$ were found within $5 \mathrm{~km}$.

Since dispersal is critical to the invasion process, understanding species-specific modes of dispersal can aid land managers with plans to limit invasion. Predicting dispersal of woolly adelgid allows land managers to anticipate which stands of subalpine fir may become infested given the current distribution of balsam woolly adelgid and location of subalpine fir stands within $5 \mathrm{~km}$. While the current dispersal model is not able to predict one-third of new infestations, it does provide insight into dispersal and predicts where two-thirds of new infestations will occur. The model also suggests other dispersal mechanisms which may improve our understanding of the expansion of this invasive species. Further research in areas such as movement along transportation corridors may improve prediction of movement.

Survey from aircraft is expensive. From a practical perspective, narrowing the search direction and establishing 


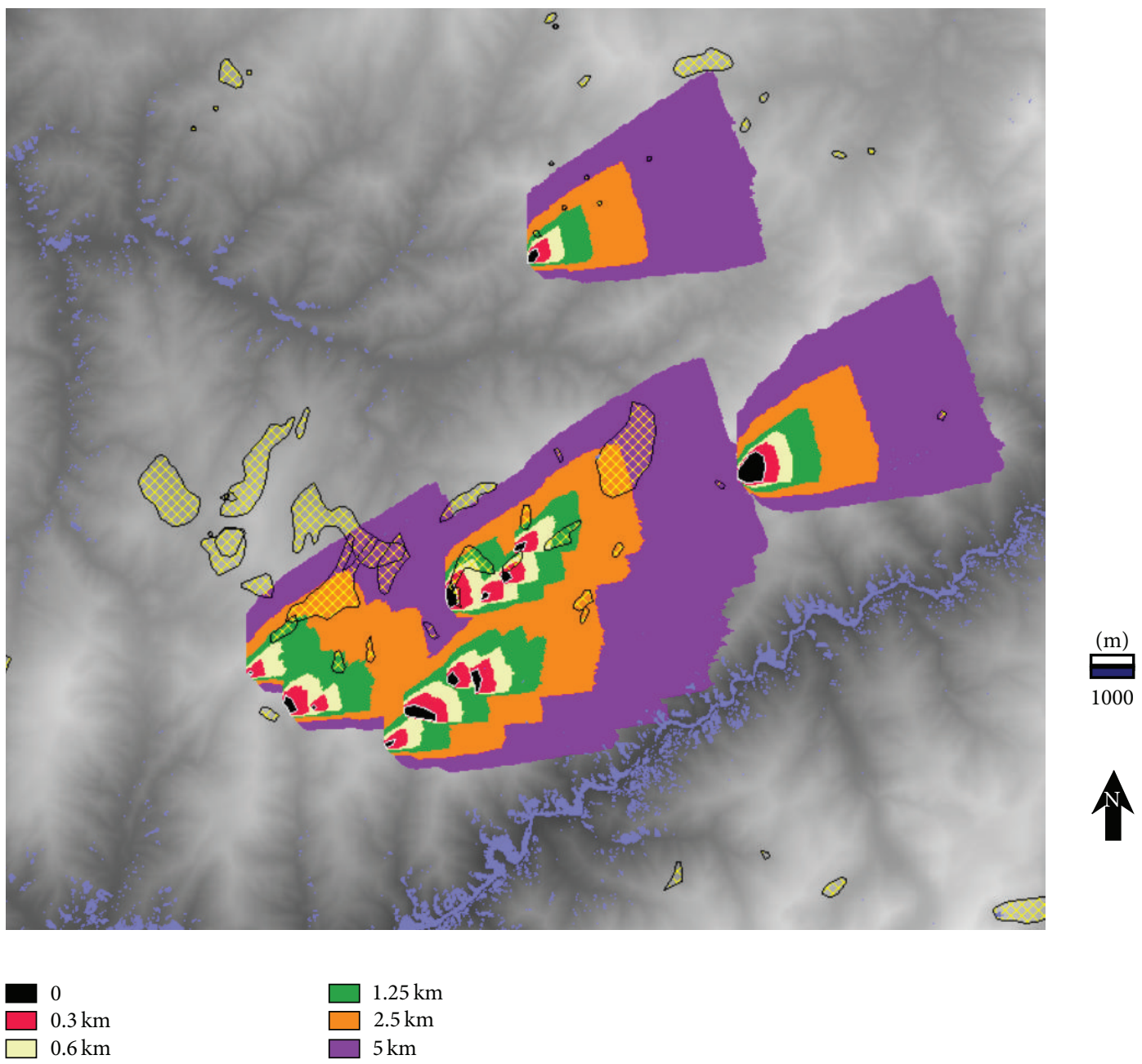

FIGURE 5: August wind dispersal model showing BWA (yellow crosshatched = BWA infestations found 12 to 16 years after initial survey, blue represents areas unlikely to support subalpine fir, and background layer is elevation).

limits to length of a survey will improve the efficiency of survey. Improving efficiency allows limited resources to be used for other aspects of management. Building speciesspecific dispersal models enhances our efforts to manage along invasion fronts.

In conclusion, we offer several distinct suggestions for surveys and implications for management. First, wind direction changes through the summer and so understanding local wind patterns in July and August will improve selection of areas to survey for new infestations. Second, new infestations will be found within $5 \mathrm{~km}$ of older infestations and relatively new infestations likely will be closer together, likely within $2.5 \mathrm{~km}$. Third, openings in a canopy will increase dispersal since wind increases as canopy height and density decrease so any changes in the landscape that decreases canopy height and density will increase dispersal of woolly adelgid. Examples include fire, timber harvest, and road building. Finally, wind-based dispersal models may allow managers to find two-thirds of infestations and other modes of dispersal must be considered if additional infestations must be found.

\section{Conflict of Interests}

The authors declare that there is no conflict of interests regarding the publication of this paper.

\section{Acknowledgment}

The authors wish to thank USDA CSREES IntegratedNational Research Initiative Competitive Grants Program (2008-02991) for funding.

\section{References}

[1] R. E. Balsch, Studies of the Balsam Woolly Aphid, Adelges Piceae (Ratz.) and Its Effects on Balsam Fir, Abies, (L.) Mill, vol. 867, Canadian Department of Agriculture Publication, 1952.

[2] F. P. Hain, "The balsam woolly adelgid in North America," in Dynamics of Forest Insect Populations, A. A. Berryman, Ed., pp. 87-109, Plenum Press, New York, NY, USA, 1988.

[3] I. R. Ragenovich and R. G. Mitchell, Balsam Woolly Adlegid, USDA-Forest Service, Forest Insect and Disease Leaflet, 2006. 
[4] R. G. Mitchell, "Infestation characteristics of the balsam woolly aphid in the Pacific Northwest," USDA-Forest Service Research Paper PNW-35, U.S. Forest Service, 1966.

[5] R. L. Livingston, J. E. Dewey, D. P. Beckman, and L. E. Stipe, "Distribution of the balsam woolly adelgid in Idaho," Western Journal Applied Forestry, vol. 15, pp. 227-231, 2000.

[6] R. G. Mitchell, "Abnormal ray tissue in three true firs infested by balsam woolly aphid," Forest Science, vol. 13, pp. 327-332, 1967.

[7] F. H. Smith, "Effects of balsam woolly aphid (Adelges piceae) infestation on cambial activity in Abies grandis," American Journal Botany, vol. 54, pp. 1215-1223, 1967.

[8] A. H. Doerksen and R. G. Mitchell, "Effects of the balsam woolly aphid upon wood anatomy of some western true firs," Forest Science, vol. 11, pp. 181-188, 1965.

[9] G. S. Puritch and R. P. C. Johnson, "Effects of infestation by the balsam woolly aphid, Adelges Piceae (ratz.) on the ultrastructure of bodered-pit membranes of grand fir, Abies grandis (doug.) lindl," Journal of Experimental Botany, vol. 22, no. 4, pp. 953958, 1971.

[10] G. S. Puritch, "Effects of water stress on photosynthesis, respiration, and transpiration of four Abies speices," Canadian Journal of Forest Research, vol. 3, pp. 293-298, 1973.

[11] S. P. Cook, K. S. Humes, R. Hruska, G. Fraley, and C. J. Williams, "Identifying subalpine fir (Abies lasiocarpa) attacked by the balsam woolly adelgid (Adelges piceae) using spectral measurements of the foliage," International Journal of Forestry Research, vol. 2010, Article ID 498189, 8 pages, 2010.

[12] S. E. Franklin, D. R. Peddle, B. A. Wilson, and C. F. Blodgett, "Pixel sampling of remotely sensed digital imagery," Computers and Geosciences, vol. 17, no. 6, pp. 759-775, 1991.

[13] S. K. Hagle, K. E. Gibson, and S. Tunnock, "Field guide to diseases and insect pests of northern and central Rocky Mountain conifers," Tech. Rep. USFS R1-03-08, U.S. Deptartment of Agriculture, Forest Service, 2003.

[14] F. D. Johnson, Wild Trees of Idaho, University of Idaho Press, Moscow, Russia, 1995.

[15] L. W. Lass, T. S. Prather, B. Shafii, and W. J. Price, "Tracking invasive species in rangeland using probability functions to identify site specific boundaries. A case study using yellow starthistle (Centaurea solstitialis)," in GIS Applications in Agriculture, S. A. Clay, Ed., vol. 2 of Invasive Species, chapter 13, pp. 277-300, CRC Press, 2011.

[16] P. S. Thenkabail, A. D. Ward, J. G. Lyon, and P. van Deventer, "Landsat Thematic Mapper indices for evaluating management and growth characteristics of soybeans and corn," American Society of Agricultural Engineers, vol. 35, no. 5, pp. 1441-1448, 1992.

[17] A. L. O’Neill, “Satellite-derived vegetation indices applied to semi-arid shrublands in Australia," Australian Geographer, vol. 27, no. 2, pp. 185-191, 1996.

[18] F. Baret, G. Guyot, and D. J. Major, “TSAVI: a vegetation index which minimizes soil brightness effects on LAI and APAR estimation," in Proceedings of the 12th Canadian Symposium on Remote Sensing (IGARSS '90), vol. 4, pp. 1355-1358, Vancouver, Canada, July 1989.

[19] D. M. Vaughn, "Degree days," in Encyclopedia of World Climatology, J. E. Oliver, Ed., p. 316, Springer, 2005.

[20] B. G. Marcot, R. S. Holthausen, M. G. Raphael, M. M. Rowland, and M. J. Wisdom, "Using Bayesian belief networks to evaluate fish and wildlife population viability under land management alternatives from an environmental impact statement," Forest Ecology and Management, vol. 153, pp. 29-42, 2001.
[21] R. G. Pontius Jr. and K. Batchu, "Using the relative operating characteristics to quantify certainty in prediction of location of land cover change in India," Transactions in GIS, vol. 7, no. 4, pp. 467-484, 2003.

[22] I. Palomino and F. Martin, "A simple method for spatial interpolation of the wind in complex terrain," Journal of Applied Meteorology and Climatology, vol. 34, no. 7, pp. 1678-1693, 1995.

[23] T. G. Barbounis and J. B. Theocharis, "Locally recurrent neural networks optimal filtering algorithms: application to wind speed prediction using spatial correlation," in Proceedings of the International Joint Conference on Neural Networks (IJCNN '05), vol. 5, pp. 2711-2716, Ontario, Canada, August 2005.

[24] S. Li, "Wind power prediction using recurrent multilayer perceptron networks," in Proceedings of the 2003 IEEE Power Engineering Society General Meeting, vol. 4, pp. 2325-2330, July 2003.

[25] K. Sreelakshmi and P. R. Kumar, "Performance evaluation of short term wind speed prediction techniques," International Journal of Computer Science and Network Security, vol. 8, pp. 162-169, 2008.

[26] P. M. Atkinson and A. R. L. Tatnall, "Neural networks in remote sensing," International Journal of Remote Sensing, vol. 18, no. 4, pp. 699-709, 1997.

[27] J. C.-W. Chan, K.-P. Chan, and A. G.-O. Yeh, "Detecting the nature of change in an urban environment: a comparison of machine learning algorithms," Photogrammetric Engineering and Remote Sensing, vol. 67, no. 2, pp. 213-225, 2001.

[28] D. L. Civco, "Artificial neural networks for land-cover classification and mapping," International Journal of Geographical Information Systems, vol. 7, no. 2, pp. 173-186, 1993.

[29] F. Tian, B. Shafii, C. J. Williams, T. S. Prather, W. J. Price, and L. W. Lass, "Prediction of yellow starthistle survival and movement over time and space," in Proceedings of the Sixteenth Annual Kansas State University Conference on Applied Statistics in Agriculture, G. A. Milliken, Ed., pp. 74-96, Kansas State University, Manhattan, Kan, USA, 2004.

[30] M. D. Atkins and T. A. D. Woods, "Survival of the balsam woolly adphid on Abies logs," Canadian Entomologist, vol. 100, pp. 412420, 1968.

[31] T. A. D. Woods and M. D. Atkins, "A study of the dispersal of balsam woolly aphid crawliers by small animals," in Bi-Monthly Research Notes, vol. 23, p. 44, Canadian Department of Forestry and Rural Development, 1967.

[32] M. S. McClure, "Role of wind, birds, deer, and humans in the dispersal of hemolco woolly adelgid (Homoptera: Adelgidae)," Environmental Entomology, vol. 19, pp. 36-43, 1990. 

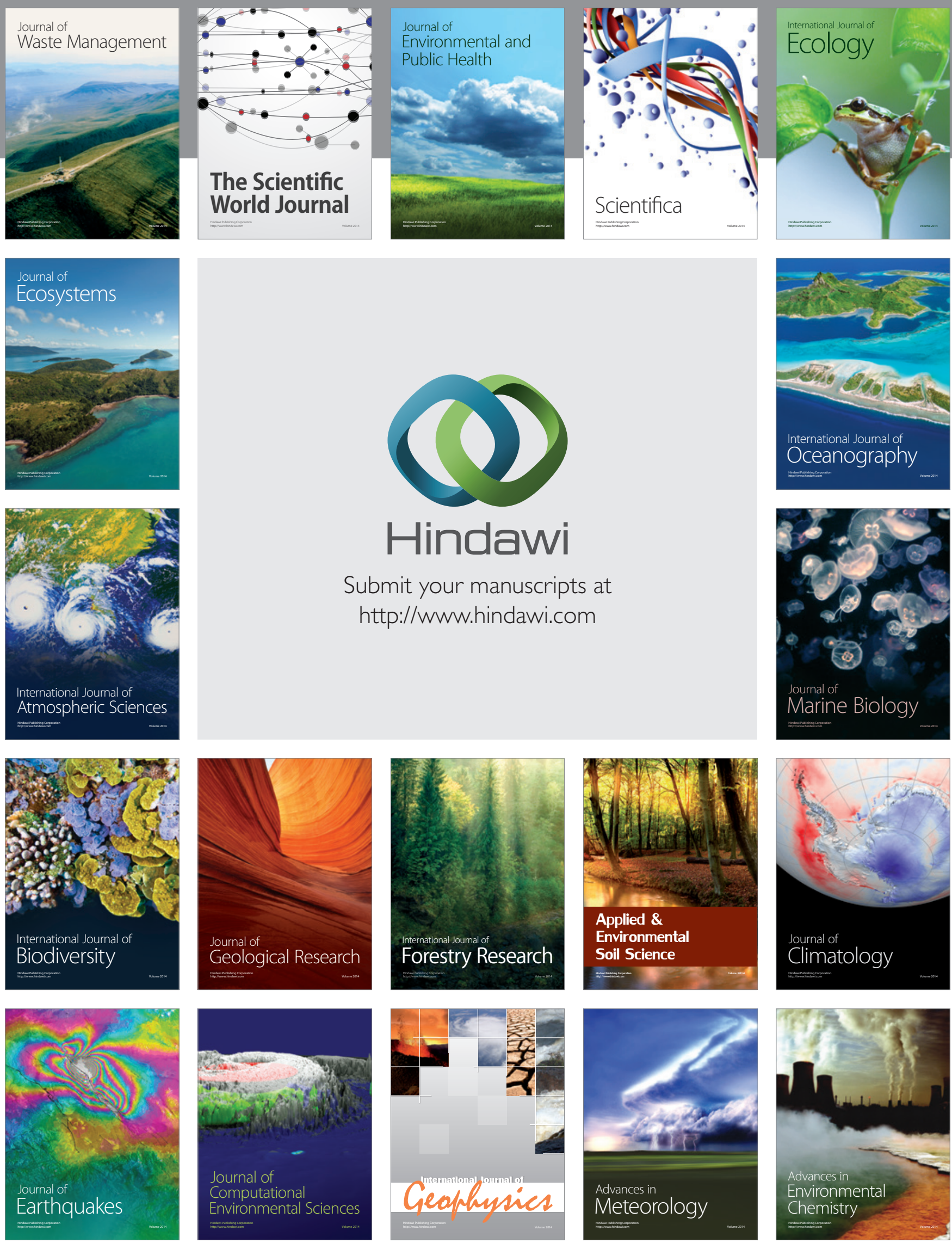